\title{
Regulation of The Provision of Covid-19 Vaccination in Indonesia as The Implementation of State Obligations in line with The Indonesian Constitution
}

\author{
Lisa Mery ${ }^{1 *}$, Andi Rahmah ${ }^{2}$, Andi Sry Rezki Wulandari ${ }^{3}$ \\ 1, 2, ${ }^{3}$ Faculty of Law Indonesia Timur University, Makassar, Indonesia \\ *E-mail: lismer1802@gmail.com
}

\begin{tabular}{l}
\hline Info Artikel \\
\hline Keywords: \\
Regulation; \\
Vaccines; \\
Constitutional \\
Mandate. \\
\\
\\
\\
DOI: \\
$10.47268 /$ sasi.v27i4.686
\end{tabular}

\begin{abstract}
This study aims to provide a clear picture of the steps (efforts) of the government of the Republicof Indonesia to provide vaccines to its people evenly and free of charge according to the standardsor procedures in the Health Law which is a derivative of the constitutional mandate of the Republic of Indonesia, the research method uses normative juridical research that combines the rule of law. With law enforcement which is a regulation of the Indonesian government, the results of the studyprovide a perspective that various ways have been attempted by the Indonesian government to overcome the Covid-19 virus pandemic, vaccines are a continuous hope to increase immunity andimmunity of community groups which will certainly have a positive impact with the release of theIndonesian state from health threats and a spike in the increase in cases during the global pandemic. The conclusion of this study is that the Indonesian government has made intensive andaccurate efforts to protect citizens and build group immunity which of course has an impact on the positive possibility that the Indonesian state and nation can get out of worries due to the Covid-19 pandemic.
\end{abstract}

\section{A. INTRODUCTION}

In general, the number of cases of Positive Covid-19 patients in Indonesia is March 17, 2021 of 4,185,144, the number of patients recovered 3,976,064 people, and death due to Covid19 approximately 140,138 people. The data showed factually that the Pandemic Covid-19 which began to be declared confirmed in Indonesia since the beginning of March 2020 to the final half of 2021 was still quite worrying. The Indonesian government takes the steps of Covid-19 vaccinations in Indonesia as the implementation of state liabilities that are in line with the Indonesian Constitution, for the initial steps listed on January 28, 2020 Head of the Ministry of Health's Health Crisis has issued specialized preparedness guidelines for the new Corona virus, PR Step While the role of the Government of the Republic of Indonesia continues intensified in the protection of greater impact prevention due to the distribution of Covid-19 with the provision of vaccines. 
According to the Prof. Dr Dr DR Nasonondin SPPD K-PTI Finim about the purpose of the vaccine, which is to provide immunity to the individual who get vaccines, vaccine injections will induce or stimulate human body cells, especially cell B to produce immunoglobulin, The rules for providing vaccines contained in the Minister of Health Regulation Number 18 of 2021 (PMK) replacing the Minister of Health Regulation Number 10 of 2021 adapted to the situation and conditions of handling Covid-19 pandemics in Indonesia. The vaccine is not traded and must be given a special sign that is easily recognized in plain view. PMK also regulates the handling of the incidence of participating after the Covid-19 vaccination that requires treatment and care at health facilities in accordance with medical indications and treatment protocols. State readiness and responsibility is contained in the health-related rules in the Pandemic Covid19 period conducted by the government is a form of the implementation of the constitutional mandate and related laws, one of which is Law Number 4 of 1984 concerning the outbreak of infectious diseases, in Article 5 of the laws DINY The Covid-19 pandemic event requires the seriousness of the government to stem the effects and minimize the number of victims of the citizens ${ }^{1}$, but the phenomenon of rejection receives this free vaccine that has occurred in the community, even a health person. The community became very worried to be given a covid-19 vaccine injection because it was affected by false information seen in social media. ${ }^{2}$

Communities in Indonesia have lied information that turns out to be from individuals or individuals and groups of people who intentionally and accidentally, are not balanced, getting digital literacy presents false information or hooks submitted continuously, reproduced with massively in public space and designed ${ }^{3}$. The government's good intentions and the constitutional mandate who want to protect and save the Indonesian people to reach this inhibited this certainly influences the various aspects of the nation and state. Because of this, the research was related to the regulation of the provision of Covid-19 vaccinations in Indonesia as the implementation of state liabilities in line with the Indonesian Constitution "will be studied further in this article by lifting the level of law enforcement.

To prevent the spread of Covid-19 cases, several countries are working to accelerate the production of the Covid-19 vaccine so that the health crisis and crises in other sectors can be quickly resolved ${ }^{4}$. To get out of the Covid-19 pandemic situation, which is actually necessary for too long is the coverage of vaccination to create group immunity. Vaccination coverage needed approximately $67 \%$. The legal basis for vaccines in Indonesia is sourced from: ${ }^{5}$

1) Undang-Undang Nomor 4 Tahun 1984 tentang Wabah Penyakit Menular (Lembaran Negara Republik Indonesia Tahun 1984 Nomor 20, Tambahan Lembaran Negara RepublikIndonesiaNomor 3273);

2) Undang-Undang Nomor 39 Tahun 2008 tentang Kementrian Negara (Lembaran Negara Republik Indonesia Tahun 2008 Nomor 166, Tambahan Lembaran Negara Republik Indonesia Nomor 5063);

3) Peraturan Presiden Nomor 99 Tahun 2020 tentang Pengadaan Vaksin dan Pelaksanaan Vaksinasi dalam rangka Penanggulangan Pandemi Corona Virus Disease 2019

4) Peraturan Menteri Kesehatan Nomor 28 Tahun 2020 tentang Pelaksanaan Pengadaan Vaksin dalam rangka Penanggulangan Pandemi Corona Virus Disease

1 Kurniawan, M. B. (2021). Politik Hukum Pemerintah dalam Penanganan Pandemi Covid-19 Ditinjau dari Perspektif Hak Asasi atas Kesehatan. Jurnal HAM, 12(1), 37-56.

2 https://www.beritasatu.com/kesehatan/717449/hoax-di-medsos-sumber-kekhawatiran-takut-divaksin. accessed 17 September 2021

3 Wirawan, A., Mery, L., \& Pajri, S. (2021). Penegakan Hukum Proses Identifikasi dan Profiling Pelaku Hoaks di Media Sosial. Petitum, 9(1), 41-50.

4 Situmeang, T., \& Murniarti, E. (2021). Asean Attitudes Toward Patent Protection of The Covid-19 Vaccine Versus Humanitarian Interests. Jurnal Hukum dan Peradilan, 10(2), 255-276.

5 https://sehatnegeriku.kemkes.go.id/baca/berita-utama/20210613/0337893/pemerintah-perbaruiaturanpelaksanaan-vaksinasi-covid-19/ . accessed 17 September 2021

452|SASI Volume 27 Issue 4, October - December 2021 


\section{B. RESEARCH METHODS}

This research is a normative juridical research by conducting a study of legal literature to secondary data. This research is a prescriptive analytical, namely research that aims to provide suggestions and alternative solution problems ${ }^{6}$. The data collection technique used in this research is the result of studies and documentation related to the role of the Indonesian government in the efforts to provide vaccines during Pandemic Covid-19. Documents as studies in the form of books, scientific journals, legislation and other documents. The data analysis method used in this study is a qualitative analysis that provides data in the form of a description of the truth of the data or the final premise of the study determined by its own researcher ${ }^{7}$

\section{RESULTS AND DISCUSSION}

The distribution control strategy and transmission of Covid-19 virus infection is carried out by conducting and adhering to the health protocol (wearing masks, hand washing, maintaining distance) and serious efforts from the government as policy stakeholders, namely $3 T$ (tracing, testing, treatment). Providing vaccines is also an actions of the Government of the Republic of Indonesia for free, with a large scale or sufficient ratio of population in Indonesia, despite meetinga number of refusions and false news made to reject vaccines, many doubts the level of effectiveness of vaccines for individuals in a community and country. Immunity Group which is avaccine goal is expected to become an antidote to the spread of the Covid-19 virus, based on research people who have twice the Covid-19 vaccination with a complete dose very potentially getting three times more protection compared to those who are not vaccinated at all. The Ministryof Health through its site "Waspada Infection" explained that from the experience of overcomingsome infectious diseases that had occurred previously without vaccines was not an effective way to achieve group immunity, this particularly can be illustrated in diseases that cause high severity and death. The Covid-19 virus can mutate, the longer so the antibodies of previous infections onlyprovide protection for a short period of time (not a lifetime). Research on the summary of the Indonesian Ministry of Health found extraordinary events (KLB) of infectious diseases (can actually be prevented by vaccine) found in community groups with low vaccination coverage so that the community does not have immune groups against infectious diseases, complete doses vaccines are an effective way to achieve immunity.

WHO “...but it's not vaccines that will stop the pandemic, it's vaccination. We must ensure fair and equitable access to vaccines, and ensure every country receives them and can roll them out toprotect their people, starting with the most vulnarable." 8

Mass vacuination is needed to reduce the case of the spread of the Covid-19 virus that continues to spread in the community, the Indonesian government initially for this vaccine program only gives the suggestion to the community to participate in a complete vaccine (two doses) as an effortto minimize the level of deployment or raising immune The speed of the spread of the Covid-19 virus by the Indonesian government is also suppressed by limiting the mobility of society, the term social restrictions on large-scale social (PSBB) and the implementation of large-scale communityactivities restrictions (PPKM) with a level of 1,2,3 and 4 for Java, Bali and other regions The Indonesian government is actively campaigning for $3 \mathrm{M}$ behavior to break the chain of the spread of the Covid-19 virus, vaccines are another effort from the Indonesian government to protect andnourish its people. Because it is the process of

6 Soekanto, S., \& Mamudji, S. (2004). Penelitian Hukum Normatif Suatu Tinjauan Singkat, Jakarta: Raja Grafindo Persada, p.1-2

${ }^{7}$ Moleong, L. J. (2005). Metode PenelitianKualitatif, Bandung: Remaja Rosda Karya, p. 24

8 https://www.who.int/emergencies/diseases/novel-coronavirus-2019/covid-19-vaccines. accessed 17 September 2021

453|SASI Volume 27 Issue 4, October - December 2021 
procuring vaccines and the implementation of vaccination into priority in careful care and handling including the observations of the development of the change / mutation of the virus ${ }^{9}$.

To achieve group immunity in Indonesia vaccine needs is certainly very large, the government strives for vaccines from various sources, including by building Indonesian cooperation with other countries. The policy of providing Covid-19 vaccine is escorted by drug regulators in Indonesia, namely through the POM agency for fulfilling the properties, security and vaccine quality, this is of course so that the community accesses Covid-19 vaccine that has met the standards and requirements in the right time by publishing:

1) Vaksin CoronaVac (Sinovac),

2) Vaksin COVID-19 Bio Farma,

3) Vaksin AstraZeneca,

4) Vaksin Sinopharm,

5) Vaksin Moderna,

6) Vaksin Comirnaty (Pfizer dan BioNTech),

7) Vaksin Sputnik-V.

The POM continues to appeal to the public to take a vaccination program so that the body's immune system and achieved immune groups, and continue to implement a health protocol consistently, as a key effort in breaking the chain of the spread of the spread of Covid19 deployment ${ }^{10}$. Virus Virus Virus-19 Will and have provided by the Government of Indonesia, but the challenge of spreading this vaccine is not easy, the number of false news, negative campaigns and various opinions that are illegal in the Indonesian people, making regulating vaccination in various areas of the Indonesian Unitary State Data between September 182021 shows the number of doses that have been given by 125 million doses, 45.1 million doses for complete vaccination meaning in general Indonesia has done a complete $16.7 \%$ of the population of the population. (Our World in Data, September 18 The data if explained in the total population is less than 79,657,762 the first dose, for the second dose of 45,224,650 people, or equivalent to $21,71 \%{ }^{11}$. The conclusion of this study that the Indonesian Government has made intensive and accurate efforts to protect citizens and build group immunity which certainly affects the possibility of positive countries and nations of Indonesia can get out of fears due to covid pandemics.

\section{CONCLUSION}

Vaccines are a way that the governments of every country, including Indonesia, are trying to prevent from being exposed to or experiencing severe symptoms of Covid-19, protecting others from the potential for contracting/infecting, stopping the spread of Covid-19, and helping protectthe next generation. Learning from the history of vaccines has saved the world from pandemics several times, vaccines are valuable findings from the world of science. Although it is not yet perfect in carrying out the constitutional mandate, especially Article $28 \mathrm{H}$ paragraph (1) and Article34 paragraph (2) and (3) of the 1945 Constitution regarding the government's duty to protect the right to health of the Indonesian people, various prevention and handling measures for the Covid-19 pandemic have been sufficient. Significantly providing space for citizens to feel the role of thegovernment, that the government is present and protects its citizens, this is a good step and the Indonesian government must continue to improve its efforts.

\footnotetext{
9 Kurniawan, M. B. Op. Cit.

10 https:/www.pom.go.id/new/view/more/pers/622/SIARAN-PERS-Tambah-Pilihan-Jenis-VaksinCOVID- 19-di-Indonesia--Badan-POM-Terbitkan-EUA-untuk-Janssen-COVID-19-Vaccine-dan-VaksinConvidecia.html diakses pada Minggu, accessed 19 September 2021

11 https://www.merdeka.com/peristiwa/data-terkini-vaksinasi-dosis 1-dan-2-di-indonesia-20september2021.html, accessed 20 September 2021
}

454|S A S Volume 27 Issue 4, October - D e cember 2021 


\section{REFERENCES}

\section{Jurnal}

[1] Kurniawan, M. B. (2021). Politik Hukum Pemerintah dalam Penanganan Pandemi Covid19 Ditinjau dari Perspektif Hak Asasi atas Kesehatan. Jurnal HAM, 12(1), 37-56.

[2] Situmeang, T., \& Murniarti, E. (2021). Asean Attitudes Toward Patent Protection of The Covid-19 Vaccine Versus Humanitarian Interests. Jurnal Hukum dan Peradilan, 10(2), 255-276.

[3] Wirawan, A., Mery, L., \& Pajri, S. (2021). Penegakan Hukum Proses Identifikasi dan Profiling Pelaku Hoaks di Media Sosial. Petitum, 9(1), 41-50.

\section{Buku}

[4] Moleong, L. J. (2005). Metode PenelitianKualitatif, Bandung: Remaja Rosda Karya.

[5] Soekanto, S., \& Mamudji, S. (2004). Penelitian Hukum Normatif Suatu Tinjauan Singkat, Jakarta: Raja Grafindo Persada.

\section{Online/World Wide Web, Disertasi dll}

[6] https://www.beritasatu.com/kesehatan/717449/hoax-di-medsos-sumber-kekhawatirantakut-divaksin.

[7] https://www.merdeka.com/peristiwa/data-terkini-vaksinasi-dosis 1-dan-2-di-indonesia20-september2021.html.

[8] https://www.who.int/emergencies/diseases/novel-coronavirus-2019/covid-19-vaccines.

[9] https://www.pom.go.id/new/view/more/pers/622/SIARAN-PERS-Tambah-Pilihan-JenisVaksin-COVID- 19-di-Indonesia--Badan-POM-Terbitkan-EUA-untuk-Janssen-COVID19-Vaccine-dan-Vaksin-Convidecia.html diakses pada Minggu.

[10] https://sehatnegeriku.kemkes.go.id/baca/berita-utama/20210613/0337893/pemerintahperbaruiaturan-pelaksanaan-vaksinasi-covid-19/ . accessed 17 September 2021. 